\title{
KONSEP PENDIDIKAN YANG DI TERAPKAN PENDIRI PESANTREN KHOIRU UMMAH (KYAI HAJI SYAHRONI SYAFLY ABDUL AZIZ)
}

\section{Zaenal Arifin}

Madrasah Aliyah Khoiru Ummah, Yayasan Khoiru Ummah

Email: zainelghozy81@gmail.com

\begin{abstract}
Abstrak
Berbicara tentang konsep, strategi, tujuan, dan sistem penerapan pendidikan memang tak ada hentinya. Ini menunjukkan betapa pentingnya ilmu melalui pendidikan. Tujuan dilakukannya penelitian ini adalah untuk mengetahui salah satu konsep yang diterapkan oleh pendiri lembaga pondok pesantren modern Khoiru Ummah desa Waitila Kecamatan Seram utara timur seti. Beliau bernama KH. Syahroni Syafli Abdul Aziz dan untuk mengetahui keberhasilan pendidikan yang diterapkan oleh beliau. Selain dari tujuan tersebut adalah untuk mengetahui keberhasilan yang telah dicapai para alumni santri ponpes Khoiru Ummah Maluku tengah. Metode yang digunakan untuk pengumpulan data dalam penelitian ini adalah bersumber dari Pendiri Pesantren Khoiru Ummah dan pengamatan langsung selama proses belajar mengajar di Pesantren Khoiru Ummah. Pengumpulkan data dan menganalis data, pengumpulan data penelitian menggunakan wawancara dengan para pendiri khoiru ummah, observasi dan studi kepustakaan terhadap sumber-sumber literasi terkait dengan penelitian yang ditemukan didalam penelitian ini bahwa Konsep Pendidikan yang diterapkan oleh KH. Syahroni Sayfli Abdul Azis adalah dengan memadukan konsep pendidikan umum, konsep pendidikan agama, dan skill santri. Konsep pendidikan three in one (tiga konsep dalam satu terapan) ini yang secara rinci melahirkan santri berpendidikan umum (ketaatan santri terhadap Negara), berpendidikan agama (taat kepada Tuhan dan berakhlak mulia), dan pembekalan skill (lebih mengarah pada bakat) untuk ketahanan dia hidup atau bekerja. Dari Penerapan konsep pendidikan terpadu inilah yang sangat melekat pada diri santri sehingga sesuai data membuktikan bahwa alumni Khoiru Ummah mampu bersaing dalam hal keagamaan, birokrasi, instansi pemerintah, aparatur sipil Negara, linimasi bisnis, seniman dengan tetap menjaga akhlak atau budi pekerti yang baik.
\end{abstract}

Kata Kunci: konsep; pendidikan; pesantren; kyai

\section{Abstract}

Talking about the concepts, strategies, goals, and systems of application of education is indeed endless. It shows how important science is through education. The purpose of this research is to find out one of the concepts applied by the founder of the modern boarding school institution Khoiru Ummah village Waitila Seram District north east seti. His name is KH. Shahroni Syafli Abdul Aziz and to find out the success of education applied by him. Aside from this goal is to find out the success that has been achieved by alumni santri ponpes Khoiru Ummah Maluku

$\begin{array}{ll}\text { How to cite: } & \text { Arifin, Z., (2021) Konsep Pendidikan yang Di Terapkan Pendiri Pesantren Khoiru Ummah (Kyai } \\ & \text { Haji Syahroni Syafly Abdul Aziz). Syntax Idea, 3(9): https://doi.org/10.36418/syntax-idea.v3i9.1494 } \\ \text { E-ISSN: } & \text { 2684-883X } \\ \text { Published by: } & \text { Ridwan Institute }\end{array}$


central Maluku. The method used for data collection in this study is sourced from the Founder of Pesantren Khoiru Ummah and direct observation during the teaching and learning process at Pesantren Khoiru Ummah. Data gathering and analyzing data, collecting research data using interviews with the founders of khoiru ummah, observation and literature studies on literacy sources related to the research found in this study that the Concept of Education applied by KH. Syahroni Sayfli Abdul Azis is by combining the concept of general education, the concept of religious education, and santri skills. The concept of education three in one (three concepts in one terapan) that in detail gives birth to a generally educated santri (santri obedience to the State), religious education (obedient to God and noble conduct), and pembekalan skill (more towards talent) for the resilience of him to live or work. From the application of the concept of integrated education is very attached to the santri seto the data proves that Khoiru Ummah alumni are able to compete in religious matters, bureaucracy, government agencies, state civil apparatus, business lines, artists while maintaining good morals or ethics.

Keywords: concept; education; pesantren; kyai

\section{Pendahuluan}

Pendidikan adalah suatu sistem yang sasarannya diarahkan kepada terciptanya perubahan sikap dan tungkah laku peserta didik. Sebagaimana amanat Undang-undang No.2 tahun 1989 bahwa pendidikan Nasional bertujuan:"mencerdaskan kehidupan bangsa dan mengembangkan manusia seutuhnya, yaitu manusia yang beriman dan bertakwa terhadap Tuhan Yang Maha Esa, serta berbudi Pekerti luhur, memiliki pengetahuan dan keterampilan, kesehatan jasmani dan rohani, kepribadian yang mantap dan mandiri serta rasa tanggung jawab kemasyarakatan dan kebangsaan" (Nurgiansah, 2021).

Dari rumusan diatas terlihat bahwa keimanan dan ketakwaan kepada Tuhan Yang Maha Esa adalah salah satu dari tujuan pendidikan nasional.

Menurut (Akhirin, 2015) bahwa tujuan akhir pendidikan Islam adalah merealisasikan penghambaan kepada Alloh SWT. dan berbuat baik kepada sesame manusia secara individual maupun sosial. Sementara itu (Hidayatullah, 2019) menyatakan bahwa tujuan pendidikan Islam adalah merealisasikan manusia muslim yang beriman dan bertakwa kepada Alloh SWT; berilmu pengetahuan untuk mengabdikan diri kepada kholiknya .

Dengan demikian tampak bahwa antara tujuan pendidikan nasional dengan tujuan pendidikan Islam ada kesamaan, yakni sama-sama menciptakan manusia yang beriman dan bertakwa kepada Tuhan Yang Maha Esa serta berperilaku baik sesama manusia (Ruslan, 2016).

Masalah pendidikan Islam lebih luas dari pada pengajaran Islam. Karena pendidikan Islam selain mengajar dalam arti menyampaikan ilmu juga melakukan pembinaan akhlak yang sesuai dengan nilai-nilai ajaran Islam. Dengan adanya lembaga pendidikan Islam mampu melahirkan manusia yang bertakwa kepada Tuhan Yang Maha 
Esa dan berakhlak mulia yang mana segala tindakan sesuai dengan nilai-nilai ajaran Islam (Hidayat, 2016).

Untuk menjamin originalitas penelitian ini, penulis paparkan penelitian terdahulu yang dilakukan oleh Darlis Darlis, "Peran Pesantren As'adiyah Sengkang dalam Membangun Moderasi Islam di Tanah Bugis", 2016. Darlis berupaya mengungkap konsep moderasi Islam yang diajarkan dan didakwahkan oleh perguruan As'adiyah. Hasil penelitiannya menemukan; 1) konsep dasar moderasi Islam perguruan As'adiyah Sengkang bermuarapada tiga hal, yaitu tauhid, syariat dan tasawuf; 2) mengubah kepercayaan animesme yang merajalela di Tana Wajo menjadi pemahaman tauhid yang benar; 3) melalui pendekatan anregutta, perguruan As'adiyah berhasil membendung serangan aliran keras. Pendekatn anregutta yaitu pendekatan dengan mengadakana perkumpulan dengan masyarakat untuk berdzikir dan beritual (Abdullah, 2019).

Ciri-ciri orang yang beriman dan bertakwa kepada Tuhan Yang Maha Esa, paling tidak memiliki ciri-ciri sebagai berikut: (1.) Mempercayai agama sescara utuh (2.) Berpengetahuan tentang agama yang dianut. (3.) Berperilaku sesuai dengan ajaran agamanya (4.) Peka terhadap masalah sosial sebagai makhluk individu dan warga masyarakat (Azis, 2019).

Pondok Pesantren Khoiru Ummah yang didirikan sekaligus diasuh oleh Kyai syahroni syafli Abdul Aziz merupakan salah satu lembaga pendidikan yang memadukan antara tujuan pendidikan Nasional dan Tujuan pendidikan Islam dengan menambahkankan pembekalan keterampilan atau skill santri.

Menjadi bagian dari santri kyai syahroni sejak saya masih berada dipesantren khoiru ummah hingga saat ini diberi amanat oleh para pendiri ponpes khoiru ummah untuk memimpin Madrasah Aliyah, merupakan pengalaman emas bagi saya pribadi.

Satu hal yang cukup menggelitik dalam pikiran saya adalah bagaimana konsep yang diterapkan oleh beliau dalam proses pembelajaran dikhoiru ummah sehingga menjadikan lembaga khoiru ummah menggapai keberhasilan semasa beliau masih ada.

Hal ini yang melatarbelakangi saya untuk memberanikan diri menulis bagaimana konsep keberhasilan pendidikan yang diterapkan oleh kyai Syahroni pendiri sekaligus pengasuh pertama yayasan pondok pesantren khoiru ummah.

Tujuan penelitian yang dilakukan adalah untuk mengukur Konsep Pendidikan Yang Di Terapkan Pendiri Pesantren Khoiru Ummah (Kyai Haji Syahroni Syafly Abdul Aziz).

\section{Metode Penelitian}

Metode yang digunakan untuk pengumpulan data dalam penulisan ini bersumber dari Pendiri Pesantren Khoiru Ummah dan pengamatan langsung selama proses belajar mengajar di Pesantren Khoiru Ummah. Pengumpulkan data dan menganalis data, pengumpulan data penelitian menggunakan wawancara dengan para pendiri khoiru ummah, observasi dan studi kepustakaan terhadap sumber-sumber literasi terkait dengan penelitian. 


\section{Hasil dan Pembahasan}

Sebelum dibahas lebih dalam mengenai bagaimana penerapan konsep Kyai Syahroni dalam proses pembelajaran di khoiru ummah mari kita bahas pengertian dari konsep dan pendidikan.

1. Pengertian konsep

Konsep atau anggitan adalah abstrak, entitas mental yang universal yang menunjuk pada kategori atau kelas dari suatu entitas, kejadian atau hubungan. Istilah konsep berasal dari bahasa latin conceptum, artinya sesuatu yang dipahami (https://id.wikipedia.org/wiki/Konsep, 2018).

Konsep dalam hal ini merupakan gambaran ide yang di terapkan oleh kyai syahroni dalam proses pembelajaran di Khoiru ummah untuk menentukan keberhasilan pendidikan yang diselenggarakan oleh yayasan pesantren khoiru ummah.

2. Pengertian Pendidikan

Pendidikan adalah sebagai usaha sadar dan terencana untuk mewujudkan suasana belajar dan proses pembelajaran untuk peserta didik secara aktif mengembangkan potensi dirinya untuk memiliki kekuatan spiritual keagamaan, pengendalian diri, kepribadian, kecerdasan, akhlak mulia, serta keterampilan yang diperlukan dirinya dan masyarakat (Fitria, Marsidin, \& Nirwana, 2016).

Pendidikan dapat diartikan sebagai usaha sadar dan sistematis untuk mencapai taraf hidup atau untuk kemajuan lebih baik. Secara sederhana, Pengertian pendidikan adalah proses pembelajaran bagi peserta didik untuk dapat mengerti, paham, dan membuat manusia lebih kritis dalam berpikir (http://www.artikelsiana.com, 2018).

Pendidikan umum berarti pendidikan yang bertujuan mengembangkan sikap, kemampuan, dan tingkah laku yang diinginkan oleh masyarakat, tetapi tidak dimaksudkan untuk menyiapkan siswa menguasai keterampilan untuk pekerjaan tertentu (https://www.apaarti.com/pendidikan-umum.html, 2018).

Pendidikan umum merupakan pendidikan dasar dan menengah yang mengutamakan perluasan pengetahuan yang diperlukan oleh peserta didik untuk melanjutkan pendidikan ke jenjang yang lebih tinggi (Wirta, 2017).

Saya menyimpulkan bahwa pendidikan umum sasarannya lebih mengarah kepada hubungan baik sebagai warga negara terhadap sesama dalam hal urusan dunia, sebagai bekal melangsungkan kebutuhan hidup seseorang. Seperti memilih pendidikan atau jurusan di perkuliahan, memilih calon pemimpin dalam pemilu, melamar pekerjaan atau profesi tertentu, dan lain sebagainya.

Pendidikan agama adalah pendidikan yang memberikan pengetahuan dan membentuk sikap, kepribadian, dan keterampilan peserta didik dalam mengamalkan ajaran agamanya, yang dilaksanakan sekurang-kurangnya melalui mata 
pelajaran/kuliah pada semua jalur, jenjang, dan jenis pendidikan. (PP-55-07/2) (Susanto \& Kustianing, 2019).

Selaras dengan tujuan dan fungsi pendidikan agama menurut PP No 55 tahun 2007 pasal 2, dapat disimpulkan bahwa tujuan dan fungsi dari pendidikan agama adalah membentuk manusia Indonesia yang beriman dan bertakwa, taat kepada perintah tuhan, meninggalkan hal-hal yang larangNya, membentuk generasi yang agamis dan nasionalis, guna dengan tujuan mampu memahami, menghayati, dan mengamalkan nilai-nilai agama yang menyerasikan penguasaannya dalam ilmu pengetahuan, teknologi dan seni (Yasyakur, 2017).

Pendidikan Life skill adalah proses pembelajaran menjadikan peserta didik berkemampuan dan memiliki keberanian untuk menghadapi problema kehidupan kemudian secara proaktif dan kreatif mencari dan menemukan solusi untuk mengatasinya. Tujannya adalah memberikan bekal dalam menghadapi dan memecahkan problema hidup dan kehidupan, baik sebagai kehidupan pribadi yang mandiri, warga masyarakat, maupun sebagai warga negara.dengan hasil yang dapat mencapai apa yang menjadi tujuan hidupnya (Rohmah, 2017).

Dalam hal pendidikan life skill ini konsep yang digunakan oleh kyai syahroni adalah mengklasifikasikan bakat yang dimiliki santri, pihak pesantren memberikan pembelajaran sekaligus pelatihan kepada santri sehingga output atau lulusan dari pesantren diharapkan bisa menjadi pebisnis, birokrat, akademisi, politisi, seniman, petani dan sebagainya. Konsep inilah yang terus menerus mewarnai sistem pendidikan Ponpes Khoiru Ummah hingga mampu bertahan sampai saat ini.

Hasil pengamatan saya selama mengikuti proses pembelajaran di pondok pesantren khoiru ummah selama kurang lebih delapan tahun, serta hasil wawancara dari beberapa tokoh pendiri saat "acara napak tilas sejarah berdirinya pondok pesantren Khoiru ummah", menunjukkan bahwa konsep pendidikan yang diterapkan oleh Kyai Syahroni adalah konsep pendidikan "Three In One”.

Maksudnya adalah tiga penerapan program pendidikan yang berajalan dalam satu kurikulum pendidikan pesantren.

Tiga program tersebut adalah pesantren Khoiru ummah mengkolaborasikan tiga kebutuhan pendidikan yang harus dimiliki manusia dalam mencapai tujuan kehidupan, yakni "sa'idun fi al-dunya wa sa'idun fi al-akhiroti", artinya bahagia didunia dan bahagia di akhirat. kolaborasi yang dimaksud antara lain pendidikan umum, pendidikan agama, dan pendidikan life skill.

Konsep "three in One" dalam penerapannya tentu tidak terlepas dari standar kurikulum nasional. Hadirnya kyai Syahroni dengan tujuan Mencerdaskan seluruh peserta didik atau santri Khoiru ummah yang nantinya kembali ke masyarakat menjadi manusia beriman dan bertaqwa kepada Alloh SWT, yang cerdas akal dan hatinya, mempunyai karakter dan kepribadian yang mulia, siap hidup mandiri di masyarakat.

Saya simpulkan Tiga kata kunci dari "konsep pendidikan three in one" yang diterapkan oleh kyai syahroni cukup sederhana. Baik kepada Ilahi, Baik kepada 
Negeri dan baik kepada Diri sendiri. Baik yang dimaksud bukan semata-mata hanya berbuat baik terhadap tiga komponen tersebut diatas, melainkan di atas. Melainkan harus berani melarang dan mencegah perbuatan buruk yang dilakukan oleh orang lain. Entah perbuatan buruk itu terhadap tuhan, terhadap negri, atau terhadap pelaku perbuatan itu sendiri.

Keburukan berarti Tiga ranah tersebut jika terpenuhi dengan Dengan kata lain mewujudkan santri yang bisa bekerja untuk negeri, mengerjakan perintah ilahi, dan bekerja untuk Diri Sendiri.

Setelah santri menguasai ilmu umum, artinya dia harus bisa berbuat yang terbaik dalam urusan berbangsa dan bernegara, menjunjung tinggi harkat dan martabat manusia, memelihara toleransi, menerima keberagaman bangsa dan saling menghargai.

Setelah santri menguasai ilmu agama, harus mengamalkan segala yang diperintahkan oleh ilahi, dan meninggalkan semua larangaNya. Bukan hanya sebatas pemenuhan tuntutan kognitif kurikulum mata pelajaran agama, melainkan melakoni semua ilmu agama yang telah dipelajari.

Setelah santri menguasai pendidikan life skill, santri harus bisa berdikari, mandiri dalam berwira usaha, guna mencukupi kebutuhan duniawi.

Bukti keberhasilan dan prestasi yang pernah digapai pada masa kyai syahroni oleh santri pondok pesantren khoiru ummah adalah sebagai berikut :

- Tahun 1997-1999, Santri ponpes khoiru ummah menjadi mitra pencatatan rekening PLN (contoh ril penguasaan pendidikan Skill)

- Tahun 1997, Santri ponpes khoiru ummah menjadi mitra pemerintah dalam program ABRI Manunggal Hutan Cadangan Pangan (contoh ril penguasaan pendidikan Skill)

- Tahun 1998-2000,Santri ponpes khoiru ummah menjadi khotib tetap dan muballigh bulanan di masjid-masjid sekitar pondok pesantren khoiru ummah. (contoh ril penguasaan pendidikan agama)

- Tahun 1998-2000,Santri ponpes khoiru ummah diminta menjadi pelatih kegiatan olah raga dan seni di beberapa sekolah yang membutuhkan (contoh ril penguasaan pendidikan umum)

- Tahun 1998-sekarang Santri ponpes khoiru ummah mampu memproduksi karya seni yang menyebar ke seluruh penjuru Negeri. (contoh ril penguasaan pendidikan Skill)

- Tahun 1997-1999,Santri ponpes khoiru ummah mampu memproduksi ribuan bibit okulasi, stek dan grafting (contoh ril penguasaan pendidikan Skill)

- Tahun 2002, Santri ponpes khoiru ummah mampu menjuarai lomba pidato Pospenas di Indramayu (contoh ril penguasaan pendidikan Skill)

- Tahun 1997,Santri ponpes khoiru ummah menjuarai pameran pembangunan pada peringatan Hari Jadi Kota Masohi 
Konsep pendidikan yang di terapkan pendiri Pesantaren Khoiru Ummah Kh. Syahroni Syafly Abdul Aziz

- Tahun 1997-sekarang, Santri ponpes khoiru ummah menjuarai menjuarai MHQ/MKQ tingkat Provinsi dan delegasi ke tingkat Nasional (contoh ril penguasaan pendidikan Skill)

- Tahun 1997-sekarang, Santri ponpes khoiru ummah selalu aktif membuat Pameran dan BAZAR dalam event-event penting. (contoh ril penguasaan pendidikan Skill)

- Tahun 2014, salah satu santri Khoiru ummah menjadi delegasi Pramuka mengunjungi enam Negara di Asia tenggara. (contoh ril penguasaan pendidikan Skill)

Dan masih banyak karya santri ponpes khoiru ummah yang tidak sempat saya tulis, karna beberapa dokumen dan pelaku sejarah sudah sulit di jumpai.

\section{Kesimpulan}

Berdasarkan penelitian yang telah dilakukan, maka dapat disimpulkan bahwa:1.) Konsep pendidikan yang diterapkan oleh Kyai Syahroni adalah konsep pendidikan “Three In One”, yaitu Maksudnya adalah tiga penerapan program pendidikan yang berajalan dalam satu kurikulum pendidikan pesantren. pendidikan umum, pendidikan agama, dan pendidikan life skill. Dengan meracik tiga ranah pokok kebutuhan pendidikan tesebut, diharapkan santri mampu bekerja untuk negeri, mengerjakan perintah ilahi, dan bekerja untuk Diri Sendiri. 2.) Dengan menggunakan konsep Kyai Syahroni, Ketercapaian Keberhasilan pendidikan di pondok pesantren khoiru ummah "sangat berhasil". 


\section{BIBLIOGRAFI}

Abdullah, Mukhammad. (2019). Mengurai Model Pendidikan Pesantren Berbasis Moderasi Agama: dari Klasik ke Modern. Prosiding Nasional, 2, 55-74. Google Scholar

Akhirin, Akhirin. (2015). Pengembangan Potensi Anak Perspektif Pendidikan Islam. Tarbawi: Jurnal Pendidikan Islam, 12(2). Google Scholar

Azis, Rosmiaty. (2019). Ilmu Pendidikan Islam. Universitas Islam Negeri Alauddin Makassar Google Scholar

Fitria, Rini, Marsidin, Sufyarma, \& Nirwana, Herman. (2016). Hubungan Persepsi siswa tentang budaya sekolah dan motivasi belajar dengan penyesuaian diri siswa. Konselor, 3(4), 139-146. Jurnal Fitri Wahyuni fkm. Google Scholar

Hidayat, Rahmat. (2016). Ilmu Pendidikan Islam Menuntun Arah Pendidikan Islam Indonesia. Lembaga Peduli Pengembangan Pendidikan Indonesia, Medan. Google Scholar

Hidayatullah, Asep Saya. (2019). Kerjasama Dan Kompetensi Untuk Meningkatkan Moral Kelompok. An-Nidhom: Jurnal Manajemen Pendidikan Islam, 4(2), 37-52. Google Scholar

http://www.artikelsiana.com. (2018).

https://id.wikipedia.org/wiki/Konsep. (2018).

https://www.apaarti.com/pendidikan-umum.html. (2018).

Nurgiansah, T. Heru. (2021). Pendidikan Pancasila. CV. Mitra Cendekia Media. Google Scholar

Rohmah, Lailatu. (2017). Available online on: http://ejournal. uin-suka. ac. id/tarbiyah/alathfal. Google Scholar

Ruslan, Ruslan. (2016). Kontribusi Pendidikan Islam Terhadap Pendidikan Nasional. Jurnal Ilmiah Mandala Education, 2(1), 475-481. Google Scholar

Susanto, Rizki, \& Kustianing, Utien. (2019). Pelaksanaan Ekstrakurikuler Pendidikan Agama Islam Di Sekolah: Studi di SMPN 3 Malang Tahun 201. JRTIE: Journal of Research and Thought of Islamic Education, 2(1). Google Scholar

Wirta, I. Komang. (2017). Kompleks Sekolah Dasar dan Menengah Pertama di Kota Malang.Repository ITN MALANG. Google Scholar 
Konsep pendidikan yang di terapkan pendiri Pesantaren Khoiru Ummah Kh. Syahroni Syafly Abdul Aziz

Yasyakur, Moch. (2017). Strategi Guru Pendidikan Agama Islam dalam Menanamkan Kedisiplinan Beribadah Sholat Lima Waktu. Edukasi Islami: Jurnal Pendidikan Islam, 5(09), 35.Google Scholar

Copyright holder:

Zaenal Arifin (2021)

First publication right:

Syntax Idea

This article is licensed under:

(c) (i) (?) 